\title{
IMPLEMENTASI KEBIJAKAN KUOTA BAGI PENYANDANG DISABILITAS UNTUK MENDAPATKAN PEKERJAAN DI KOTA YOGYAKARTA
}

\author{
Utami Dewi ${ }^{1}$
}

\begin{abstract}
This article aims to describe the implementation of the quota policy 1 percent of employment opportunities for persons with disabilities in the city of Yogyakarta as stated in Government Regulation No. 43 Year 1998 on Efforts to Increase Social Welfare of Persons with Disabilities. In addition, a study of the obstacles encountered and efforts made by the Government of the city of Yogyakarta is also a goal of writing this article. The method used in this research is qualitative descriptive. The author uses interview, observation and documentation for data collection. The results showed that the implementation of the quota policy 1 percent for disabled for agencies that have hired employees more than 100 people, has not run optimally in the city of Yogyakarta. This is demonstrated by the limited number of disabled absorbed in government and private agencies. Various obstacles encountered in the implementation of this policy, namely: training materials for the disabled less up to date, enforcement of regulations about 1 percent quota has not run optimally; low awareness of state agencies and private companies to employ persons with disabilities; and the lack of willingness of the disabled to find jobs.
\end{abstract}

Keywords: Quota Policy, Employment, Disabled

\begin{abstract}
Abstrak
Artikel ini bertujuan untuk mendeskripsikan implementasi kebijakan kuota 1 persen kesempatan kerja bagi penyandang disabilitas di Kota Yogyakarta seperti termaktup dalamPeraturan Pemerintah No 43 Tahun 1998 tentang Upaya Peningkatan Kesejahteraan Sosial Penyandang Cacat. Selain itu, kajian tentang hambatan dihadapi dan upaya yang dilakukan oleh Pemerintah Kota Yogyakarta juga menjadi tujuan dari penulisan artikel ini. Metode yang digunakan dalam penelitian artikel ini adalah deskriptif kualitatif. Penulis menggunakan wawancara, observasi dan dokumentasi untuk pengumpulan data. Hasilpenelitian menunjukkan bahwa implementasi kebijakan kuota 1 persen bagi disabel bagi instansi yang telah mempekerjakan pegawai lebih dari 100 orang, belum berjalan dengan optimal di Kota Yogyakarta. Hal ini ditunjukkan dengan masih terbatasnya jumlah disable yang terserap pada instansi pemerintah maupun swasta. Berbagai hambatan dihadapi dalam implementasi kebijakan ini yaitu: materi pelatihan bagi kaum disabel kurang up to date, penegakan regulasi tentang kuota 1 persenbelum berjalan dengan optimal; rendahnya kesadaran dari instansi negeri dan perusahaan swasta untuk mempekerjakan penyandang disabilitas; dan rendahnya kemauan dari kaum disabel untuk mencoba mencari pekerjaan pada lapangan kerja yang tersedia.
\end{abstract}

Kata kunci: Kebijakan Kuota, Pekerjaan, Disabel PENDAHULUAN

\footnotetext{
${ }^{1}$ Dosen, Jurusan Ilmu Adminsitrasi Negara, Fakultas Ilmu Sosial, Universitas Negeri Yogyakarta. email: utami.dewi@uny.ac.id
} 
Menjadi disabel sering diidentikkan dengan ketidakberuntungan dalam hidup karena kesulitan dalam mendapatkan keadilan dan persamaan hak baik dalam bidang pendidikan, kesehatan, sosial dan akses terhadap sarana prasarana bangunan atau gedung. Keadaan seperti ini menyebabkan kelompok disabel menjadi kelompok minoritas yang kadang terlepas dari jangkauan pemerintah. Padahal, kelompok disabel adalah juga warga negara yang memiliki hak dan kewajiban yang sama dengan warga negara lainnya.

Kecacatan seharusnya tidak menjadi halangan bagi penyandang disabilitas untuk memperoleh hak hidup dan hak mempertahankan kehidupannya. Landasan konstitusional bagi perlindungan penyandang disabilitas di Indonesia, dapat dilihat dalam ketentuan Pasal 28 A UUD 1945, yakni : "Setiap orang berhak untuk hidup serta berhak mempertahankan hidup dan kehidupannya". Hak untuk hidup adalah hak asasi yang paling dasar bagi seluruh manusia. Hak hidup merupakan bagian dari hak asasi yang memiliki sifat tidak dapat ditawar lagi (non derogable rights).

Hak hidup mutlak harus dimiliki setiap orang, karena tanpa adanya hak untuk hidup, maka tidak ada hak-hak asasi lainnya.
Menurut hasil Survey Sosial Ekonomi Nasional (Susenas) yang dilaksanakan Biro Pusat Statistik (BPS) tahun 2012, jumlah penyandang disabilitas di Indonesia sebanyak 6.008.661 orang. Dari jumlah tersebut sekitar $\quad 1.780 .200$ orang adalah penyandang disabilitas netra, 472.855 orang penyandang disabilitas rungu wicara,402.817 orang penyandang disabilitas grahita/intelektual, 616.387 orang penyandang disabilitas tubuh, 170.120 orang penyandang disabilitas yang sulit mengurus diri sendiri, dan sekitar 2.401 .592 orang mengalami disabilitas ganda (Kemensos, https://kemsos.go.id/2015).

Sesungguhnya pemerintah tidak melupakan hak yang harus dipenuhi bagi kelompok minoritas, yaitu penyandang disabilitas. Sejumlah kebijakan telah di keluarkan untuk menjamin hak bagi penyandang disabilitas. Undang-undang No 4 tahun 1997 tentang Penyandang Cacat menegaskan bahwa para penyandang disabilitas memiliki sejumlah hak seperti yang termaktup dalam pasal 13 yang berbunyi: "Setiap penyandang cacat mempunyai kesamaan kesempatan untuk mendapatkan pekerjaan sesuai dengan jenis dan derajat kecacatannya". Hal itu juga tercantum dalam Pasal 14 UndangUndang Nomor 4 tahun 1997 Tentang Penyandang Cacat yang menyebutkan 
bahwa: "Perusahaan negara dan swasta memberikan kesempatan dan perlakuan yang sama kepada penyandang cacat dengan mempekerjakan penyandang cacat di perusahaannya sesuai dengan jenis dan derajat kecacatan, pendidikan, dan kemampuannya, yang jumlahnya disesuaikan dengan jumlah karyawan dan atau kualifikasi perusahaan" (UU No 4/1997).

Bahkan lebih tegas pula diatur kuota untuk memberi kesamaan kesempatan bagi penyandang cacat tersebut. Peraturan tentang kuota diatur secara jelas dalam Peraturan Pemerintah Republik Indonesia Nomor 43 Tahun 1998 Tentang Upaya Peningkatan Kesejahteraan Sosial Penyandang Cacat yang terdapat dalam Pasal 28 yang berbunyi: "Pengusaha harus mempekerjakan sekurang-kurangnya 1 (satu) orang penyandang cacat yang memenuhi persyaratan jabatan dan kualifikasi pekerjaan sebagai pekerja pada perusahannya untuk setiap 100 (seratus) orang pekerja perusahaannya" (Pasal 28 Peraturan Pemerintah Republik Indonesia Nomor 43 Tahun 1998 Tentang Upaya Peningkatan Kesejateraan Sosial Penyandang Cacat).

Dalam kenyataannya, kebijakan kuota satu persen bagi penyandang cacat seakan masih jauh dari kenyataan. Masih banyak perusahaan yang meski mempekerjakan lebih dari 100 orang ternyata tak mempekerjakan satu orang pun penyandang cacat atau pun hanya mempekerjakan satu orang saja, padahal perusahaan tersebut memiliki lebih dari 200 orang pekerja (Rizano, 2014).

Bagi perusahaan, alasan mendasar untuk tidak mempekerjakan kaum disabel adalah untuk efektifitas produksi. Pada dasarnya pekerja merupakan bagian dari faktor produksi yang sangat penting bagi perusahaan, karena dapat mempengaruhi kegiatan perusahaan. Hal tersebut dikarenakan pekerja merupakan faktor produksi yang dapat mengelola faktor produksi lain perusahaan (Nababan, 2009).Diharapkan pekerja dapat mengelola faktor produksi lain perusahaan dengan baik sehingga pada akhirnya perusahaan dapat mencapai tujuan perusahaan secara efektif dan efisien, antara lain menekan biaya produksi dan meningkatkan keuntungan perusahaan.Oleh karena itu pengusaha dalam merekrut pekerja sangat berhatihati, sehingga dapat mempekerjakan pekerja yang memiliki kualitas dan dapat bekerja maksimal bagi perusahaan.

Penyandang disabilitas bagi sebagian orang salah satunya pengusaha, masih dipandang sebagai seseorang yang tidak dapat bekerja dengan baik dan tidak memiliki keahlian. Bahkan masih banyak pihak yang menganggap penyandang 
disabilitas sebagai seseorang yang tidak sehat secara fisik maupun mental. Hal ini menyebabkan pengusaha ragu mempekerjakan penyandang disabilitas, dan menyebabkan kuota $1 \%$ tersebut masih sulit dilaksanakan (Suara Pembaharuan, http://www.suara pembaharuan.com/ home/ penyandang disabilitas masih alami diskriminasi/45903, Jakarta, 2 Juli 2014).Sebagai upaya perlindungan hukum hak-hak warga negara penyandang cacat maka diperlukan sebuah penataan regulasi yang mampu melindungi warga penyandang cacat.

Kota Yogyakarta sebagai pusat perekonomian di Daerah Istimewa Yogyakarta menjadi sasaran bagi pencari kerja dimana sebagian besar industri dan lapangan kerja berada. Jumlah penyandang disabilitas di DIY meningkat sejak terjadi gempa bumi yang terjadi pada tahun 2006. Kajian ini difokuskan di Kota Yogyakarta karena meningkatnya jumlah penyandang disabilitas akibat gempa 2006 dan faktor Yogyakarta sebagai daerah percontohan dalam menerapkan kebijakan inklusif di Indonesia. Artikel ini akan menganalisis bagaimana penerapan kebijakan kuota satu persen melalui Peraturan Pemerintah Republik Indonesia Nomor 43 Tahun 1998 Tentang Upaya Peningkatan Kesejahteraan Sosial Penyandang Cacat.
Selain itu, upaya-upya yang telah dilakukan oleh pemerintah untuk meningkatkan keterserapan penyandang disabilitas pada dunia kerja juga akan dikaji dalam artikel ini.

\section{METODE PENELITIAN}

Metode dalam penelitian ini adalah deskriptif dengan pendekatan kualitatif. Data diperoleh melalui hasil penelitian penulis pada penelitian sebelumnya. Selain itu, data berupa kajian pustaka (literature review) dan dokumentasi juga digunakan dalam penulisan artikel ini. Teknik pemeriksaan keabsahan data menggunakan triangulasi metode dimana validitas data dicek menggunakan beberapa metode. Terakhir, teknik analisis data menggunakan teknik analisis interaktif Miles dan Huberman.

\section{HASIL DAN PEMBAHASAN}

Pelaksanaan Kuota Pekerjaan Bagi Disabilitas

Undang-undang No. 4 tahun 1997 menegaskan bahwa disabel merupakan bagian masyarakat Indonesia yang juga memiliki kedudukan, hak, kewajiban, dan peran yang sama. Mereka juga mempunyai hak dan kesempatan yang sama dalam segala aspek kehidupan dan penghidupan. Pada pasal 6 dijelaskan bahwa setiap disabel berhak memperoleh: 
1. pendidikan pada semua satuan, jalur, jenis, dan jenjang pendidikan;

2. pekerjaan dan penghidupan yang layak sesuai jenis dan derajat kecacatan , pendidikan, dan kemampuannya;

3. perlakuan yang sama untuk berperan dalam pembangunan dan menikmati hasil-hasilnya;

4. aksesibilitas dalam rangka kemandiriannya;

5. rehabilitasi, bantuan sosial, dan pemeliharaan taraf kesejahteraan sosial; dan

6. hak yang sama untuk menumbuhkembangkan bakat, kemampuan, dan kehidupan sosialnya, terutama bagi disabel anak dalam lingkungan keluarga dan masyarakat.

Pada prakteknya disabel memang diberikan hak-hak tersebut. Hak atas pendidikan, hak atas pekerjaan sesuai kecacatan, aksesibilitas, dan yang lainnya. Akan tetapi hak tersebut semata mata difasilitasi oleh pemerintah tanpa ada pengarahan kepada disabel dan masyarakat keluarga penyandang cacat tersebut. Contohnya dalam praktek pendidikan yang diberikan pemerintah berupa SLB. Pemerintah membangun SLB walaupun dengan jumlah yang belum memadai. Akan tetapi minimnya sosialisasi dari pemerintah tentang pendidikan disabel ini menciptakan pengekangan hak tersebut dalam keluarga para penyandang cacat.

Anggapan tentang kecacatan yang merupakan sebuah penyakit yang tidak dapat lagi disembuhkan membuat keluarga disabel berputus asa dan beranggapan bahwa mereka tidaklah membutuhkan pendidikan. Padahal disabel sama halnya dengan orang lain. Hanya keterbatasan fisiklah (dan mental bagi penyandang tuna grahita) yang membuat mereka 'berbeda' dari orang lain. Dan perbedaan tersebut pada dasarnya bukan alasan mereka mempunyai hak asasi yang berbeda dari orang lain. Lain lagi kasusnya pada hak mendapatkan pekerjaan yang layak bagi disabel yang pada intinya tetap saja perhatian masyarakat dan pemerintahlah yang dituntut lebih dibanding apa yang masyarakat punya pada saat ini.

Selain UU No. 4/1997, pemerintah juga telah mengeluarkan Peraturan Pemerintah Nomor 43 Tahun 1998 tentang Upaya Peningkatan Kesejahteraan Sosial Penyandang Cacat. Pengaturan aksesibilitas pelayanan lebih lanjut bagi disabelsecara lebih jelas dan gamblang diatur dalam Peraturan PemerintahNomor 43 Tahun 1998 tentang Upaya Peningkatan Kesejahteraan Sosial Penyandang Cacat. Disabeldalam PP ini 
dijamin kesamaan kesempatan dalam hak, kewajiban dan perannya sesuai dengan kemampuannya dalam kehidupan berbangsa dan bernegara. Agar disabel dapat berperan serta secara maksimal maka aksesibilitas bagi disabel dijamin.

Kebijakan terbaru berkaitan dengan disabel khususnya di Daerah Istimewa Yogyakarta adalah Peraturan Daerah No 4 tahun 2012 tentang Perlindungan dan Pemenuhan Hak-Hak Penyandang Disabilitas. Perda ini mencakup tentang penerapan pendidikan inklusi, pekerjaan kepada disabel (adanya penghargaan kepada perusahaan yang memberikan pekerjaan kepada disabel), kebijakan jaminan pembiayaan kesehatan daerah kepada disabel serta beberapa kebijakan layanan yang sudah mulai berpihak kepada disabel. Pasal 3 Perda ini menegaskan bahwa Pemerintah Daerah DIY menjamin hak-hak kaum disabel meliputi hak dalam bidang pendidikan, ketenagakerjaan, kesehatan, sosial, seni, budaya, olah raga, politik, hukum, penanggulangan bencana, tempat tinggal, dan aksesibilitas.

Sejumlah kebijakan tersebut ternyata belum mampu menjadi jaminan bahwa hak-hak disabilitas khususnya dalam mendapatkan pekerjaan dan penghidupan yang layak terpenuhi. Peraturan Pemerintah No 43 Tahun 1998 tentang Upaya Peningkatan Kesejahteraan
Sosial Penyandang Cacat dan Perda DIY No 4 Tahun 2012 tentang Perlindungan dan Pemenuhan Hak-Hak Penyandang Disabilitas, yang secara eksplisit menyatakan tentang ketentuan kuota pekerjaan bagi penyandang disabilitas maupun penghargaan bagi perusahaan yang telah mempekerjakan disabel, belum menjamin hak mendapatkan pekerjaan.

Dalam bidang pengembangan tenaga kerja, Dinas Sosial membantu dalam menyalurkan kaum disabel dalam mencari kerja. Dalam Undang-Undang dan Peraturan Pemerintah, termasuk Perda No 4 tahun 2012 tentang Perlindungan Dan Pemenuhan Hak-Hak Penyandang Disabilitas disebutkan bahwa perusahaan yang mempunyai 100 pekerja, maka harus memasukkan 1 (satu) kaum disabel untuk dipekerjakan pada perusahaan tersebut. Namun perusahaan juga mempunyai kriteria dalam memasukkan kaum disabel tersebut dan ini bersifat tidak memaksa.

Dinas Sosial memberikan penghargaan kepada perusahaan yangmenempatkan kaum disabel di perusahaannya dalam bentuk pemberian gaji sebesar $25 \%$ dari gaji yang diberikan oleh perusahaan tersebut selama 1 ( satu ) tahun dan memberikan Jaminan Sosial Tenaga Kerja.

Pada tahun 2009, ada sebanyak 60 orang disabel yang disalurkan oleh Dinas Sosial kepada perusahaan di Kota 
Yogyakarta. Salah satunya adalah perusahaan jahit di daerah Kota Gede yang kebetulan pemilik dari perusahaan tersebut juga kaum disabel. Pada perusahaan swasta yang lain, seperti Andi Ofset, juga belum memenuhi kebijakan kuota tersebut. Jumlah disabel yang bekerja pada perusahaan ini belum sebanding dengan jumlah seluruh tenaga kerjanya. Hal ini juga terjadipada Hotel Grand Quality Kota Yogyakarta, yang juga belum mempekerjakan kaum disabel (Lastika Pebriana, 2014).

Hambatan yang menyebabkan penyediaan aksesibilitas kerja bagi pekerja penyandang cacat yang bekerja di Hotel Grand Quality antara lain, kurang pemahaman pihak Hotel Grand Quality Yogyakarta tentang bagaimana pemenuhan aksesibilitas bagi pekerja penyandang cacat sesuai dengan peraturan perundang-undangan, dan pekerja penyandang cacat tidak menginginkan adanya perbedaan hak dengan pekerja yang tidak cacat (Lastika Pebrina, 2014).

Sementara itu, bagi sebagian penyandang tuna netra (khususnya yang tergabung dalam Ikatan Tunanetra Muslim Indonesia/ITMI) kesempatan kerja bagi mereka agak lebih terbuka. Iffatus Shalekhah (2014) menyatakan bahwa beberapa anggota ITMI bekerja sebagai guru dan pekerja mandiri yaitu berprofesi sebagai pemijat.
Dalam rangka memenuhi hak-hak disabilitas khususnya dalam mendapatkan pekerjaan, sesungguhnya pemerintah melalui dinas sosial maupun kerja sama dengan dinas yang lain telah melakukan sejumlah upaya berupa pendidikan, pelatihan dan penyaluran kerja yaitu melalui Loka Bina Karya. Manfaat dan tujuan dari Loka Bina Karya adalah:

1. Menyelenggarakan pelayanan dan rehabilitasi sosial kepada penyandang cacat

2. Menfasilitasi usaha kesejahteraan sosial

3. Menyelenggarakan pelayanan dan rehabilitasi sosial meliputi penyuluhan dan bimbingan sosial, peletihan ketrampilan kerja, penyaluran dan bimbingan lanjut

4. Menyelenggarakan kegiatan usaha ekonomis produktif yang bersifat kooperatif

Penyelenggaraan kegiatan Loka Bina Karya (LBK) dilaksanakan selama 3 bulan dengan jumlah peserta untuk 5 LBK 75 orang (masing-masing LBK 15 Orang)Selama mengikuti kegiatan di LBK para peserta mendapatkan fasilitas konsumsi,kelengkapan peserta tempat menginap perlengkapan mandi biaya kesehatan bahan dan alat untuk praktek ketrampilan uang transport dan paket 
bantuan stimulant. Adapun kegiatan di LBK meliputi :

1. Rekuitmen(Pendekatan awal,Motivasi, Seleksi)

2. Assesmen (Pencandran terhadap penca untuk mengetahui kemampuan

fisik,sosial,Psikologis,ketrampilan ,minat dan bakat)

3. Bimbingan mental dan sosial

4. Ketrampilan dan usaha/kerja yang pernah dilatihkan meliputi: ketrampilan Jahit bordir, pertukangan kayu, las, anyam anyaman, kerajinan kulit, sablon dan batik.

Instansi lembaga terkait yang dilibatkan dalam penyelenggaraan kegiatan di LBK disanping Dinas Sosial Propinsi DIY sebagai leading sector,adalah; Kelompok Latihan Kerja/Balai Latihan Kerja; Dinas Tenaga Kerja; Dinas Perindustrian; Puskesmas; Kecamatan dan Tenaga Ahli/Swasta.

Selain melalui LBK yang dikoordinatori oleh Dinas Sosial DIY, Dinas Sosial dan Ketenagakerjaan Kota Yogyakarta juga memberikan serangkaian pelatihan kepada disabel untuk meningkatkan kemampuan dan ketrampilan para penyandang disabilitas, meliputi pelatihan kerja; Pelatihan Tenaga Kerja Mandiri; dan Pelatihan Teknis (contohnya : bordir dan jahit). Dalam rangka pembinaan tenaga kerja Aksus (Angkatan Kerja Khusus) dimana didalamnya termasuk tenaga kerja penyandang cacat (penca/ disabel), Dinas Tenaga Kerja dan Transmigrasi Daerah Istimewa Yogyakarta menyelenggarakan Kegiatan Pemberdayaan Tenaga Kerja Penca (Disabel) yang pelaksanaannya dari dana APBN. Kegiatan ini diikuti oleh 20 orang penyandang cacat (Disabel), yang keseluruhannya merupakan penyandang cacat fisik (tuna daksa). Selama mengikuti kegiatan ini, peserta memperoleh bekal pengetahuan kewirausahaan dan bantuan sarana usaha, yaitu 10 orang usaha warung kelontong dan 10 orang usaha pengolahan makanan kecil.Materi yang diberikan kepada peserta antara lain: Motivasi Usaha; Pengelolaan Usaha Kelontong; Cara Menentukan Jenis Usaha;Pengelolaan Usaha Makanan Kecil; Strategi Pemasaran; Manajemen Produksi; Pengelolaan Ekonomi Rumah Tangga; Pembukuan Praktis Usaha Kecil; Kalkulasi Usaha; Mengenal Lembaga Keuangan; dan Pembuatan Proposal Usaha.

Narasumber-narasumber pada kegiatan ini berasal dari Dinas Sosial dan Tenaga Kerja (Disnakertrans) Propinsi Daerah Istimewa Yogyakarta, Ardhana, SMEDC UGM, Komunitas Hijau,SMKN 4 Yogyakarta dan praktisi pengusaha yang menyampaikan Success Story. Selain 
memperoleh materi di dalam kelas, para peserta juga mengikuti Praktek Kerja Lapangan (PKL) pada Toko Usaha Pertanian di daerah Gentan, Jalan Kaliurang, milik Bapak Ir. Marjoko yang sebelumnya juga memberikan materi kepada para peserta. Selain PKL di Toko Usaha Pertanian, para peserta juga diberikan pelatihan praktek pengolahan makanan kecil, dengan instruktur dari SMKN 4 Yogyakarta. Setelah mengikuti pelatihan, peserta memperoleh pengetahuan kewirausahaan, baik teori maupun praktek, dengan harapan termotivasi untuk menjadi wirausaha mandiri yang pada akhirnya dapat memperluas lapangan pekerjaan bagi orang lain pada umumnya dan disabel pada khususnya.

Dari jenis pelatihan yang diberikan kepada disabel, tampaknya programprogram yang ditawarkan telah tidak lagi mampu menjawab kebutuhan disabel akan keterampilan praktis siap kerja. Disamping frequensi pelatihannya yang masih minim, jenis pelatihan yang ditawarkan juga telah tidak lagi mengikuti kebutuhan dunia kerja. Di saat dunia kerja sudah merambah generasi multi media dan computer, pelatihan-pelatihan bagi disabel masih berhenti pada menjahit, pertukangan dan sablon. Pada akhirnya, lulusannya hanyalah kembali menjadi buruh yang tidak lagi up to date dengan keterampilan-keterampilan yang dibutuhkan oleh pasar kerja. Belum lagi jika melihat testimony beberapa disabel yang merasakan dan mengetahui persis bagaimana pelatihan-pelatihan semacam itu diselenggarakan hanya sebagai proyek pemerintah semata. Hal tersebut menunjukkan bahwa disabel, sejauh ini masih ditempatkan sebatas obyek, dan bukan subyek yang mengetahui permasalahan dan kebutuhan mereka.

Kegiatan pelatihan dan pemberdayaan bagi disabel di Kota Yogyakarta dilakukan rutin dan berkelanjutan. Dinas Sosial Kota Yogyakarta juga melakukan kegiatan pelatihan rutin pada Balai Latihan Kerja dan pusat-pusat rehabilitasi penyandang cacat. Dinas Sosial juga bekerja sama dengan Dinas Ketenagakerjaan untuk menyalurkan para disabel ini. Selain itu Dinas Sosial juga menjalin kemitraan dengan pihak swasta dalam penyaluran tenaga kerja disabel.

Namun demikian, kuota 1 persen bagi penyandang disabilitas tampaknya belum dapat secara optimal tercapai di Kota Yogyakarta. Berdasarkan teori Van Meter dan Van Horn terdapat beberapa variabel yang mempengaruhi implementasi kebijakan yaitu:

1. Standar dan sasaran kebijakan Dalam hal standar dan sasaran kebijakan, kebijakan kuota 
1 persen bertujuan untuk memberikan kesempatan kepada para disabel untuk memperoleh haknya melalui kesamaan peluang untuk memperoleh pekerjaan. Standar yang diharapkan dari kebijakan kuota $1 \%$ adalah keterserapan para disabel dalam dunia kerja. Sementara itu, sasaran dari kebijakan ini adalah para disabel yang selama ini belum mendapatkan persamaan hak dalam memperoleh pekerjaan yang layak sehingga memiliki penghidupan yang lebih baik.

Pada kenyataannya standar dari kebijakan kuota 1 persen ini belum dapat tercapai dengan optimal karena berbagai macam hambatan. Perusahaan dan instansi penerima kerja berupaya untuk merekrut pencari kerja yang mempunyai kualitas unggul dan tidak memiliki keterbatasan baik fisik maupun mental. Keterbatasan ini dianggap sebagai penghambat pencapaian kinerja dan produksi yang maksimal.

2. Sumberdaya

Sumberdaya organisasi yang terlibat dalam pelaksanaan kebijakan kuota adalah pemerintah, yaitu Dinas Tenaga Kerja dan Transmigrasi; dan Dinas
Sosial; instansi pemerintah pencari kerja; dan organisasi swasta/perusahaan swasta.Dalam hal sumberdaya, kebijakan kuota 1 persen bagi penyandang disable untuk mendapatkan pekerjaan kurang dapat terlaksana dengan optimal karena dukungan dari pemerintah dan organisasi lain kurang. Kebijakan kuota kurang efektif diimplentasikan karena pemerintah kurang menegakkan reward and punishment system. Sistem penghargaan yang diberikan kepada perusahaan yang telah merekrut kaum disabel kurang menarik sehingga tidak banyak perusahaan yang melaksanakan kebijakan kuota ini. Sebaliknya, berkaitan dengan sanksi yang diberikan juga belum tegas bahkan terkesan tidak berjalan karena tidak ada sama perusahaan yang diberi hukuman meskipun perusahaan tersebut tidak mempekerjakan penyandang disabilitas.

3. Komunikasi antar organisasi dan penguatan aktivitas

Komunikasi yang terjalin antar organisasi pelaksana kebijakan ini kurang berjalan dengan sinergis dikarenakan masing-masing pihak memiliki fokus tugas dan 
kepentingan masing-masing, yang kadang-kadang menciptakan perbedaan kebijakan atau program. Dari pihak pencari kerja baik negeri maupun swasta, pasti lah akan mencari kerja yang tidak memiliki keterbatasan fisik dan aksessibiltas demi alasan kinerja dan produktivitas kerja. Antar instansi pemerintah selaku actor utama dalam penerapan kebijakan ini yaitu Dinas Sosial dan Tenaga kerja juga kurang bersatu padu dalam menjalankan program masing-masing dinas. Beberapa pelatihan dan kegiatan rehabilitasi yang dilakukan oleh dua dinas tersebut tidak diikuti dengan pengawasan dan tindak lanjut berupa penempatan kerja bagi penyandang disabilitas. Hasilnya, para peserta pelatihan atau rehabilitasi banyak yang tidak tersalurkan kerja atau jika bekerja mereka tidak mendapatkan haknya dengan layak,misalnya upah yang sesuai dengan standar minimal.

4. Karakteristik agen pelaksana Berkaitan dengan karakteristik agen pelaksana, perbedaan tugas dan kepentingan dari pelaksana atau actor dalam penerapan kebijakan kuota ini menyebabkan efektivitas kebijakan kuota belum tercipta. Tujuan dari kebijakan kuota yaitu unruk memberikan penghidupan yang layak melalui persamaan kesempatan dalam mendapatkan pekerjaan, belum tercapai karena beberapa hambatan baik yang bersal dari instansi pemerintah, swasta atau pun penyandang disabel itu sendiri..

5. Kondisi sosial, ekonomi dan politik

Belum terlaksananya kebijakan kuota 1 persen bagi penyandang disabilitas untuk mendapatkan pekerjaan juga dipengaruhi oleh kondisi sosial, ekonomi dan politik. Kondisi sosial dan ekonomi Kota Yogyakarta dimana tidak terlalu banyak industri besar, yang mempekerjakan lebih dari 100 pekerja, menyebabkan kebijakan kuota belum banyak diadopsi oleh banyak perusahaan swasta. Usaha industri di Kota Yogyakarta masih bersifat usaha kecil dan menengah yang jumlah pekerjanya kurang dari 100 orang. Dengan demikian, belum banyak industry swasta yang wajib melaksanakan kebijakan ini. Selain itu, kaum disable sendiri juga tidak banyak yang tertarik untuk bekerja pada sektor industri 
karena keyakinan bahwa kecil kemungkinan akan diterima pada perusahaan swasta. Para disabel lebih memilih untuk bekerja mandiri atau mencari pekerjaan yang mudah untuk mendapatkan uang, misalnya meminta-minta. Secara politis, isu tentang ketimpangan kesempatan mendapatkan pekerjaan dan penghidupan yang layak bagi penyandang disabilitas bukan lah isu yang menarik bagi pemimpin dan partai politik untuk mendesak penguasa agar melaksanakan kebijakan kuota ini dengan lebih tegas.

\section{Hambatan Pelaksanaan Kebijakan}

Kuota 1 Persen Pekerjaan bagi Penyandang Disabilitas

Dalam implementasi kebijakan kuota 1 persen bagi penyandang disabilitas untuk mendapatkan pekerjaan yang layak, terdapat beberapa hambatan sehingga kebijakan tersebut belum efektif diterapkan. Hambatan-hambatan tersebut meliputi:

a. Materi pelatihan bagi kaum disabel kurang up to date sehingga penyandang disabilitas kurang terserap dalam dunia kerja.

Materi pelatihan yang diberikan pada Dinas Sosial dan Dinas Tenaga Kerja dan Transmigrasi
Kota Yogyakarta bersifat monoton dan terkesan kurang disesuaikan dengan kebutuhan lapangan kerja. Sejumlah kursus seperti menjahit, menyulam, pertukangan dan sablon. Oleh karena itu, materi training dan pelatihan harus disesuaikan dengan kebutuhan dan tuntutan dunia kerja yang saat ini misalnya komputer dan teknologi informasi lainnya.

b. Penegakan regulasi tentang kuota 1 persen bagi penyandang disabilitas untuk mendapatkan pekerjaan belum berjalan dengan optimal

Kebijakan kuota tersebut terkesan hanya berhenti pada regulasi tanpa ada tindak lanjut berupa reward and punishment yang jelas. Hal ini menyebabkan tidak banyak instansi negeri dan perusahaan swasta yang menerapkan kebijakan kuota ini. Kebanyakan perusahaan yang mempekerjakan penyandang disabilitas merupakan perusahaan skala menengah ke bawah yang kebetulan pimpinan perusahaannya adalah penyandang disabilitas.

c. Rendahnya kesadaran dari instansi negeri dan perusahaan swasta untuk mempekerjakan penyandang disabilitas. Bagi instansi 
pemerintah maupun swasta, factor kinerja dan produktivitas kerja selalu menjadi alasan untuk merekrut tenaga kerja non disabel. Apalagi di Kota Yogyakarta, dimana banyak pencari kerja dengan pendidikan tinggi, maka perusahaan pasti mencari tenaga kerja yang potensial dan tidak memiliki keterbatasan fisik apalagi mental. Hal ini dianggap akan mempengaruhi kinerja dan produktivitas perusahaan.

d. Rendahnya kemauan dari kaum disabel untuk mencoba mencari pekerjaan pada lapangan kerja yang tersedia. Penyandang disabilitas merasa enggan untuk mencari pekerjaan pada instansi pemerintah maupun swasta karena anggapan bahwa sulit bagi disabel untuk diterima bekerja. Pesimisme penyandang disabilitas ini bukan lah tanpa sebab. Pada beberapa kesempatan atau dari pengalaman orang lain, para disabel merasa dibedakan dengan para pencari kerja yang lain. Para penyandang disabilitas memilih untuk bekerja secara mandiri atau bahkan menganggur dan bergantung pada bantuan orang lain. Pada beberapa ruas jalan di Kota Yogyakarta seperti perempatan gayam, setiap pagi dan sore, sering terlihat para disabel yang meminta-minta bantuan orang lain (mengemis). Sikap ini dapat berasal dari rasa pesimisme mereka untuk mendapatkan pekerjaan atau pun juga karena sifat individu para disabel yang kurang mau bekerja keras.

\section{Upaya Dalam mewujudkan Kebijakan}

\section{Kuota 1 Persen Pekerjaan bagi Penyandang Disabilitas}

Berdasarkan hambatan-hambatan yang ditemui dalam pelaksanaan kebijakan kuota 1 persen bagi penyandang disabilitas untuk memperoleh pekerjaan, berikut ini beberpa upaya yang telah dilakukan oleh pemerintah, swasta dan lembaga swadaya masyarakat untuk mengatasi hambatan tersebut:

1. Instansi pemerintah yang berwenang dalam memberikan pelatihan telah menambah materi pelatihan dan training mengikuti kebutuhan dunia kerja (up to date). Pada penderita tuna daksa sudah mulai diberikan materi berkaitan dengan computer dan teknologi informasi. Pelatihan dilaksanakan di Dinas Sosial dan Dinas Tenaga Kerja Kota Yogyakarta atau di Pusat Rehabilitasi Penyandang Disabilitas di Pundong, Kabupaten 
Bantul yang merupakan pusat rehabilitasi bagi seluruh penyandang disabilitas di Daerah Istimewa Yogyakarta.

2. Pemerintah meningkatkan kerja sama dengan lembaga swadaya masyarakat untuk memberikan bekal pengetahuan dan pemberdayaan bagi kaum disabel. Pemerintah telah turut mendukung kegiatan-kegiatan yang dipelopori dan dikelola oleh organisasi swasta atau pun lembaga swadaya masyarakat yang berkembang di Kota Yogyakarta. Beberapa lembaga yang fokus pada pemberdayaan dan memperluas kesempatan kerja kaum disabilitas adalah Sanggar Saujana dan Yayasan Yakkum. Sanggar Saujana melaksanakan program Mitra Kerja Penyandang Disabilitas MKPD) yang salah satunya mengelola website kerjabilitas.com yaitu sistem informasi berbasis piranti lunak website dan seluler yang menjadi penghubung antara penyandang disabilitas pencari kerja dan penyedia kerja. Dengan sistem informasi ini, penyandang disabilitas bisa menempatkan profil mereka sebagai pencari kerja dan mengakses informasi tentang kesempatan kerja yang tersedia untuk mereka. Sistem ini juga menampung berbagai konten baik visual, audio, dan video, tentang kecakapan hidup (life skill) dan pengembangan diri untuk membantu penyandang disabilitas meningkatkan kemampuan mereka dalam persaingan dunia kerja.

Sementara itu Yayasan Yakkum juga melaksanakan sejumlah pelatihan dan mengelola website bagi penyandang disabilitas yang dikenal dengan BisaMandiri.com. Website ini diinisiasi

oleh BisnisUKM.com dan Pusat Rehabilitasi Yakkum (PRY) Yogyakarta.

BisaMandiri.com merupakan Sistem berbasis web dan aplikasi mobile untuk penyandang disabilitas dengan fokus pada 4 (empat) pendampingan utama, Pendidikan (Knowledge \& Skill), Bisnis (Entrepreneurship), Pasar (Marketplace), dan Jaringan Kerja (Networking). Sistem ini dilengkapi dengan berbagai konten pembelajaran dalam bentuk ebook, audio, maupun video tutorial.Secara umum, sistem ini diharapkan mampu menjembatani penyandang disabilitas untuk lebih 
mudah mengakses pendidikan, lapangan kerja, dan mampu meningkatkan perekonomian keluarga serta mampu menjadi individu yang mandiri secara utuh.

3. Pemerintah Kota Yogyakarta mulai mengimplementasikan berbagai kebijakan yang bersifat inklusif guna memenuhi kebutuhan disabel, misalnya program kota ramah disabel dan program kecamatan inklusi sejak akhir tahun 2015 yaitu Kecamatan Tegalrejo, Kecamatan Wirobrajan, Kecamatan Kotagede dan Kecamatan Gondokusuman.

4. Pemerintah Kota Yogyakarta bersama DPRD Kota Yogyakarta menyusun rencana peraturan daerah tentang disabilitas.

\section{SIMPULAN}

Kebijakan kuota 1 persen bagi penyandang disabilitas untuk mendapatkan pekerjaan pada instansi pemerintah maupun swasta belum terlaksana dengan optimal di Kota Yogyakarta. Untuk meningkatkan ketrampilan dan keterserapan penyandang disabilitas pada lapangan kerja yang tersedia, sesungguhnya Dinas Sosial Kota Yogyakarta telah melakukan sejumlah kegiatan yaitu pelatihan atau trainingdengan bekerja sama dengan dinas terkait yaitu Dinas Tenaga Kerja dan Transmigrasi, Dinas Perindustrian serta lembaga swadaya masyarakat dan instansi atau perusahaan swasta. Namun, terdapat beberapa kendala bagi penyandang disabilitas untuk terserap pada dunia kerja, diantaranya yaitu materi pelatihan bagi kaum disabel kurang up to date sehingga penyandang disabilitas kurang terserap dalam dunia kerja; penegakan regulasi tentang kuota 1 persen bagi penyandang disabilitas untuk mendapatkan pekerjaan belum berjalan dengan optimal; rendahnya kesadaran dari instansi negeri dan perusahaan swasta untuk mempekerjakan penyandang disabilitas untuk alasan produktivitas; dan rendahnya kemauan dari kaum disabel untuk mencoba mencari pekerjaan pada lapangan kerja yang tersedia.

Sejumlah upaya telah dilakukan oleh pemerintah dan seluruh stakeholder untuk memberdayakan dan meningkatkan keterserapan penyandang disabilitas pada dunia kerja, yaitu: penambahan materi pelatihan yang lebih up to date; peningkatan kerjasama pemerintah dengan LSM dalam pemberdayaan disabel dan penyaluran tenaga kerja pada instansi pemerintah dan swasta di Kota Yogyakarta; penerapan kebijakan inklusif seperti kecamatan inklusi; serta revisi kebijakan menyangkut disabel melalui 
penyusunan rancangan peraturan daerah tentang disabilitas.

Untuk meningkatkan keterserapan penyandang disabilitas pada dunia kerja dan mengoptimalkan implementasi kebijakan kuota 1 persen bagi penyandang disabilitas, penulis menyarankan beberapa hal:

1. Pemerintah perlu meningkatkan after care serviceyaitu tindak lanjut pendampingan kepada penyandang disabilitas setelah mengikuti program pelatihan dan rehabilitasi. Melalui after care service, pemerintah dapat memantau apakah para peserta pelatihan kerja telah mendapatkan pekerjaan yang sesuai dengan pelatihan yang diberikan. Selain itu, melalui kegiatan tersebut pemerintah dapat mengevaluasi apakah pelatihan kerja telah sesuai dengan tuntutan kerja saat ini atau belum.

2. Pemerintah dan seluruh komponen masyarakat perlu meningkatkan pemahaman kepada keluarga penyandang disabilitas untuk tidak malu memiliki anggota keluarga yang disabel. Dengan demikian, keluarga dapat memberikan motivasi kepada penyandang disabel untuk lebih maju dan tidak malu dalam berkompetisi mencari kerja.

3. Peningkatan penegakan hukum dalam implementasi kebijakan pro disabel (inklusi)

4. Peningkatan kerjasama dengan lembaga swadaya masyarakat dan swasta dalam upaya pemberdayaan penyandang disabilitas.

\section{DAFTAR PUSTAKA}

Heru Saputra Lumban Gaol, 2013, Pelaksanaan Perlindungan Hukum Bagi Pekerja Cacat Fisik di Yayasan Penyandang Cacat Mandiri Kabupaten Bantul, Program Sarjana Universitas Atmajaya, Yogyakarta.

Iffatus Shalehah, 2014, Kesempatan Kerja Bagi Tunanetra (Studi Kasus Terhadap Anggota Tunanetra Muslim Indonesia /ITMI), UIN Sunan Kalijaga, Yogyakarta.

Iskandar P. Nababan, 2013, Pengaruh Kompensasi Non-Finansial Terhadap Motivasi KerjaKaryawan (Studi Kasus Di PDAM Tirta Raharja Kabupaten Bandung), Fakultas Bisnis danManajemen Universitas Widyatama, Bandung.

Lastika Pebrina, 2014, Peranan Dinas Tenaga Kerja dan Transmigrasi Yogyakarta bidang Pengawasan Ketenagakerjaan Terhadap Pemberian Kesempatan Kerja Bagi Pekerja Penyandang Cacat di Hotel Grand Quality Yogyakarta, Pasca Sarjana, Universitas Gadjah Mada, Yogyakarta. 
Marthen YCNKF. Rodriquez, 2013,"Perlindungan Hukum Bagi Penyandang Cacat Untuk Memperoleh Kesempatan Kerja Di Perusahaan Sebagai Bentuk Pemenuhan Kuota 1\% Oleh Perusahaan Untuk Mempekerjakan Tenaga Kerja Penyandang Cacat ", Fakultas Hukum Universitas Atma Jaya Yogyakarta.

Rizano, 2014, "Implementasi Pemenuhan Hak Penyandang Cacat Dalam Memperoleh Pekerjaan Pada Perusahaan Negara Dan Swasta Di Kota Pekanbaru Berdasarkan Undang-Undang Nomor 4 Tahun 1997 Tentang Penyandang Cacat", Jurnal JOM Fakultas Hukum Volume I No. 2 Oktober 2014.

Sugi Rahayu dan Utami Dewi, 2012, Pelayanan Publik Bagi Pemenuhan Kebutuhan Difabel di Kota Yogyakarta, Universitas Negeri Yogyakarta, Yogyakarta.

Zulfah Latuconsina, 2014, Afirmasi Kebijakan Pemerintah Dalam Fasilitasi Kerja Bagi penyandang Disabilitas, Jurnal Pandecta, Volume 9, Nomor 2, Januari 2014.

Suara Pembaharuan, http://www.suara pembaharuan.com/ home/ penyandang disabilitas masih alami diskriminasi/45903

Undang-Undang No 4 Tahun 1997 tentang Penyandang Cacat.

Peraturan Pemerintah No 43 Tahun 1998 tentangUpaya Peningkatan KesejahteraanSosial Penyandang Cacat

Peraturan Daerah Daerah Istimewa Yogyakarta No 4 tahun 2012 tentang Perlindungan Dan Pemenuhan HakHak Penyandang Disabilitas.
Kemensos, https://kemsos.go.id/2015.

BisaMandiri.com

Kerjabilitas.com 